\title{
EFEKTIVITAS PEMBELAJARAN MATEMATIKA MELALUI MODEL ARIAS (ASSURANCE, RELEVANCE, INTEREST, ASSESSMENT, SATISFACTION) PADA SISWA SMP
}

\author{
Muhammad Rizal Usman \\ Universitas Muhammadiyah Makassar \\ rizal.usman@unismuh.ac.id
}

\begin{abstract}
Abstrak: Penelitian ini bertujuan untuk mengetahui keefektifan pembelajaran matematika melalui Model ARIAS (Assurance, Relevance, Interest, Assessment, Satisfaction) Tahun Ajaran 2018/2019. Jenis penelitian ini adalah penelitian praeksperimen yang hanya melibatkan satu kelas sebagai kelas eksperimen dengan desain penelitian The One Group Pretest-Posttest Design. Sampel dalam penelitian ini adalah kelas VII.3 sebanyak 26 orang siswa. Penelitian dilaksakanan selama 6 pertemuan. Instrumen dalam penelitian ini adalah tes untuk melihat hasil belajar siswa sebelum dan setelah diberikan model pembelajaaran, lembar observasi untuk mengamati aktivitas siswa selama pembelajaran berlangsung, lembar observasi keterlaksanaan pembelajaran untuk melihat kemampuan guru dalam mengelola pembelajaran serta lembar angket untuk mengetahui respon siswa terhadap pembelajaran matematika melalui Model ARIAS. Hasil penelitian menunjukkan bahwa: (1) Skor rata-rata tes hasil belajar matematika siswa setelah diterapkannya Model ARIAS adalah 71,19 dengan standar deviasi 10,61. Dari hasil terebut diperoleh 20 orang siswa $(76,92 \%)$ telah mencapai ketuntasan individual dan ini berarti bahwa ketuntasan secara klasikal telah tercapai, (2) Terjadi peningkatan hasil belajar siswa setelah diterapkannya Model ARIAS di mana nilai rata-rata gain ternormalisasi adalah 0,65, (3) Rata-rata skor aktivitas siswa telah memenuhi kriteria efektif yaitu 79,56\% (4) Angket respon siswa menunjukkan bahwa Model ARIAS dengan setting kooperatif mendapat respon yang positif dari siswa dengan rata-rata persentase sebesar 90,86\%. Dari hasil penelitian ini, dapat disimpulkan bahwa Model ARIAS efektif diterapkan dalam pembelajaran matematika pada siswa Kelas VII SMPN 1 Tanete Riaja.
\end{abstract}

Kata Kunci: efektivitas; matematika; Model ARIAS.

\section{PENDAHULUAN}

Pelajaran matematika memiliki banyak manfaat serta kegunaan yang dapat diimplementasikan dalam kehidupan sehari-hari. Manfaat dan kegunaan matematika dapat diimplementasikan ketika individu dapat memahami dan mengerti terhadap materi-materi yang di ajarkan setiap pembelajarannya. Namun untuk membuat seseorang atau siswa mampu memahami materi yang diajarakan tidaklah semudah mengucapkan kata yang didengar oleh telinga. Ketertarikan siswa dalam mempelajari sesuatu merupakan faktor yang sangat menunjang untuk dapat memahami materi yang dipelajari. Selain ketertarikan, kepercayaan diripun sangat dibutuhkan dalam proses pembelajaran matematika. Peran seorang guru sangatlah penting dalam hal tersebut.

Memilih serta memiliki model dan metode ataupun strategi 
pembelajaran yang kreatif bagi guru sehingga dapat menarik minat dan menumbuhkan rasa percaya diri siswa untuk belajar matematika. Namun kenyataannya saat ini pembelajaran matematika masihlah menjadi hal yang menjenuhkan bagi siswa. Dalam pembelajaran matematika siswa tidak tertarik untuk mepelajarinya secara terus menerus, siswa kurang aktif dalam pembelajaran karena kurangnya motivasi dari siswa untuk mempelajari matematika sehingga mempengaruhi hasil belajar.

Berdasarkan hasil wawancara yang dilakukan dengan guru dan siswa di SMPN 1 Tanete Riaja didapatkan informasi bahwa hasil wawancara dengan Ibu Masita S.Pd. selaku guru yaitu siswa cenderung kurang aktif dalam pembelajaran karena kurangnya semangat siswa dan mengalami kejenuhan dalam proses pembelajaran sehingga dalam pencapaian tujuan pembelajaran masih kurang maksimal, sedangkan hasil wawancara dengan siswa yaitu siswa cederung tidak memiliki semangat dalam belajar karena dalam pemikiran siswa matematika merupakan pembelajaran yang sulit untuk dipahami dan adapula siswa yang berpikir bahwa pembelajaran matematika membosankan sehingga siswa tidak memiliki ketertarikan untuk mempelajari matematika.

Model pembelajaran yang kreatif seharusnya digunakan dalam proses pembelajaran matematika. Siswa harus mampu berpikir kreatif dengan bantuan guru yang selalu memberikan umpan balik yang positif bagi setiap tindakan siswa seperti halnya menjawab pertanyaan yang dilemparkan guru untuk dijawab oleh siswa. Salah satu model pembelajaran kreatif dan terstrukur yaitu ARIAS (Assurance, Relevance, Interest, Assessment, Satisfaction).

Menurut Rahman \& Sofan (2014: 2), Model ARIAS adalah usaha pertama dalam kegiatan pembelajaran yang menanamkan raya yakin/percaya diri pada siswa bahwa mereka mampu dan dapat berhasil. Kegiatan pembelajaran ini relevan dengan kehidupan siswa, berusaha menarik dan memelihara minat/perhatian siswa. Model ARIAS terdiri dari lima komponen yaitu: Assurance (Percaya diri), Relevance (Seusia dengan Kehidupan siswa), Interest (Minat dan perhatian siswa), Assessment (Evaluasi) dan Satisfaction (Penguatan).

Model ARIAS diharapkan dapat menarik minat dan membuat semangat belajar matematika siswa terjaga terus menerus serta dapat meningkatkan rasa percaya diri siswa dalam belajar matematika sehingga siswa dapat memiliki respons yang baik terhadap pembelajaran, memiliki keaktifan dalam proses pembelajaran serta hasil belajar siswa dapat meningkat atau memiliki nilai ketuntasan yang baik.

\section{TINJAUAN TEORETIS}

Menurut Suprijono (2015: 215), Efektivitas pembelajaran merujuk pada berdaya dan berhasil guna seluruh komponen pembelajaran yang diorganisir untuk mencapai tujuan pembelajaran. Pembelajaran efektif mencakup keseluruhan tujuan 
pembelajaran baik yang berdimensi mental, fisik maupun sosial. Pembelajaran efektif memudahkan peserta didik belajar sesuatu yang bermanfaat. Untuk mencapai tujuan efektivitas pembelajaran memiliki beberapa indikator seperti halnya aktivitas siswa, respons siswa, keterlaksanaan pembelajaran serta ketuntasan hasil belajar siswa.

Menurut Suprijono (2015: 1320), Pembelajaran adalah usaha sadar dari guru untuk membuat peserta didik belajar, yaitu terjadinya perubahan tigkah laku pada diri siswa yang belajar. Perubahan didapatkan berupa kemampuan baru yang berlaku dalam waktu yang relatif lama karena adanya usaha. Pembelajaran berdasarkan makna leksikal berarti proses, cara, perbuatan mempelajari. Dalam perspektif pembelajaran, guru menyediakan fasilitas belajar bagi peserta didiknya untuk mempelajarinya. Pembelajaran berpusat pada peserta didik. pembelajaran adalah dialog interaktif. Pembelajaran merupakan proses organik dan konstruktif.

Menurut Brandt, dkk (2016: 753), Mathematical activities a variety of different skills and approaches, including computational skills, procedural strategies, logical reasoning, symbolic representations, problem-solving skills, etc. In terms of lerarning mathematics, mathematicians and mathematics educators sometimes claim that a particular teaching strategy will help students to learn and do mathematics.

Berdasarkan pendapat tersebut, Kegiatan matematika dapat diartikan kegiatan yang melibatkan berbagai keterampilan dan pendekatan yang berbeda seperti halnya keterampilan komputasi, strategi prosedural, penalaran logis, representasi simbol, keterampilan pemecahan masalah, dan lain-lain. Dalam hal belajar matematika, matematikawan, dan pendidik matematika terkadang menyatakan bahwa perlunya strategi pengajaran tertentu sehingga akan membantu siswa untuk belajar dan melakukan matematika.

Dalam pembelajaran matematika perlunya strategi pengajaran tertentu sehingga akan membantu siswa untuk belajar dan melakukan matematika. Model ARIAS merupakan salah satu model pembelajaran yang dapat membantu guru dalam mencapai tujuan pembelajaran matematika.

Model ARIAS merupakan modifikasi dari model pembelajaran ARCS (Attantion, Relenace, Confidence, Satifvaction) yang dikembangkan oleh John M. Keller. Komponen dari Model ARIAS dijabarkan menurut Rahman dan sofan (2014: 3) sebagai berikut:

a. Assurance (percaya diri); Assurance (percaya diri), yaitu berhubungan dengan sikap percaya, yakin akan berhasil atau yang berhubungan dengan harapan untuk berhasil. Dengan sikap yakin, penuh percaya diri dan merasa mampu dapat melakukan sesuatu dengan berhasil, maka siswa terdorong untuk melakukan suatu kegiatan dengan sebaikbaiknya sehingga dapat mencapai 
hasil yang lebih baik dari sebelumnya.

b. Relevance (berkaitan dengan kehidupan nyata); Relevance (relevansi), yaitu adanya hubungan yang ditunjukkan antara materi pembelajaran, kebutuhan dan kondisi awal siswa. Adanya relevansi antara materi yang dipelajari dengan kehidupan yang dialami siswa akan memberikan motivasi dalam belajar, karena siswa merasa bahwa materi yang mereka pelajari memiliki nilai, bermanfaat dan berguna bagi kehidupan mereka.

c. Interest (minat); Minat adalah kecenderungan yang tetap untuk memperhatikan dan mengenang beberapa kegiatan. Kegiatan yang diminati seseorang, diperhatikan terus menerus yang disertai dengan rasa senang. Minat besar pengaruhnya terhadap belajar, karena bila bahan pelajaran yang dipelajari tidak sesuai dengan minat siswa, siswa tidak akan belajar dengan sebaik-baiknya, karena tidak ada daya tarik baginya.

d. Assessment (evaluasi); evaluasi atau penilaian merupakan salah satu komponen sistem pengajaran. Evaluasi sebagai alat penilai hasil pencapaian tujuan dalam pengajaran, evaluasi harus dilakukan secara terus menerus.

e. Satisfaction (rasa bangga); satisfaction adalah reinforcement (penguatan) dapat memberikan rasa bangga dan puas pada siswa yang penting dan perlu dalam kegiatan pembelajaran.

\section{METODOLOGI PENELITIAN}

Jenis penelitian ini adalah penelitian pra eksperimen yang melibatkan satu kelas dan diberikan perlakuan (treatment) atau kelas eksperimen yang dalam penelitian dipilih dengan menggunakan teknik Cluster Random Sampiling. Perlakuan yang diberikan yaitu Model ARIAS pada siswa kelas VII.3 SMPN 1 Tanete Riaja dengn jumlah siswa 26 orang.

Desain penelitian yaitu One Group Pretest-Posttest Design. Dalam penelitian ini, pengamatan dilakukan sebelum perlakuan $\mathrm{X}$ diberikan. Sebelum pembelajaran berlangsung kelompok diberikan tes awal (pretest) dan setelah pembelajaran selesai maka diberikan tes akhir (postest) (Tiro \& Ahmar, 2014:27).

1. Hasil Belajar

Hasil belajar dapat diartikan sebagai suatu tolak ukur pencapaian tujuan dari suatu pembelajaran. Hasil belajar matematika siswa adalah nilai hasil tes matematika siswa setelah diajar melalui Model ARIAS. Nilai matematika dalam hal ini adalah nilai kognitif siswa. Nilai hasil belajar dalam hal ini adalah nilai hasil belajar matematika siswa pada materi bilangan bulat setelah diberikan pembelajaran dengan Model ARIAS.

2. Aktivitas Belajar

Aktivitas belajar merupakan suatu kegiatan siswa yang menimbulkan perubahan tingkah laku selama mengikuti proses pembelajaran dengan menggunakan Model ARIAS.

3. Respon Siswa 
Respon siswa merupakan upaya pengembangan proses kegiatan mental yang berupa tanggapan siswa selama mengikuti proses pembelajaran dengan menggunakan Model ARIAS.

Penelitian ini dilaksanakan dengan langkah-langkah sebagai berikut:

1. Tahap Persiapan

a. Mengurus izin pelaksanaan penelitian di SMPN 1 Tanete Riaja

b. Berkoordinasi dengan guru bidang studi matematika.

c. Menyusun dan menyiapkan perangkat pembelajaran dengan Model ARIAS.

d. Menyusun dan menyiapkan instrumen penelitian.

2. Tahap Pelaksanaan

a. Memberikan penjelasan secara singkat dan menyeluruh terhadap siswa sehubungan dengan materi yang akan diajarkan.

b. Memberikan tes awal (pretest) untuk mengetahui kemampuan awal siswa sebelum diberikan perlakuan.

c. Melakukan proses pembelajaran dengan menerapkan Model ARIAS. Pembelajaran dilakukan selama 4 kali pertemuan.

d. Observasi terhadap kemampuan guru dalam mengelola pembelajaran di setiap pertemuan. Kemampuan guru yang dimaksud adalah peneliti sedangkan yang menjadi obeservasi adalah seorang teman yang telah diamanahi sebelumnya.

a. Mengisi lembar observasi siswa untuk melihat aktivitas siswa pada saat proses belajar mengajar berlangsung.

b. Memberikan angket respons siswa mengenai tanggapan siswa tentang kegiatan pembelajaran dengan Model ARIAS.

c. Memberikan tes akhir (posttest) untuk mengetahui kemampuan siswa setelah diberikan perlakuan.

3. Tahap Akhir

f. Mengumpulkan data penelitian.

g. Menganalisis dan mendeskripsikan data yang telah diperoleh sesuai dengan variabel yang diteliti.

h. Menyusun laporan pelaksanaan dan hasil penelitian.

Adapun teknik pengumpulan data dalam penelitian, yaitu:

1. Data tentang hasil belajar diperoleh dengan menggunakan tes hasil belajar yang diberikan pada kelas eksperimen setelah diberi perlakuan. Tes hasil belajar bertujuan untuk mengetahui ukuran penguasaan siswa terhadap materi yang diberikan. Data tersebut diperoleh dari pretest dan postest. Pretest diberikan sebelum diterapkan Model ARIAS, sedangkan postest diberikan setelah diterapkan Model ARIAS. Adapun langkah-langkah pengumpulan datanya sebagai berikut:

a. Peneliti membagikan soal 
pretest diawal pertemuan dan posttest diakhir pertemuan pada masing-masing siswa.

b. Siswa menjawab soal-soal tersebut pada lembar jawaban.

c. Peneliti mengarahkan siswa untuk mendahulukan menjawab soal-soal yang dianggap mudah.

d. Siswa mengumpulkan jawabannya pada peneliti ketika selesai dan peneliti akan memeriksa jawaban tersebut.

2. Data tentang keaktifan siswa diperoleh dengan menggunakan lembar observasi aktivitas siswa pada saat pemberian tindakan melalui pengamatan. Pengamatan dilakukan terhadap siswa selama kegiatan pembelajaran berlangsung. Adapun langkahlangkah pengumpulan datanya sebagai berikut:

a. Instrumen aktivitas siswa diisi oleh observer.

b. Lembar observasi diisi dengan ketentuan observer menuliskan jumlah siswa yang melakukan aktivitas pada setiap perilaku yang diamati.

3. Data tentang respons siswa diperoleh dengan menggunakan angket respons siswa yang dibagikan setelah perlakuan diberikan. Data diambil pada saat kegiatan pembelajaran berakhir. Adapun langkah-langkah pengumpulan datanya sebagai berikut:

a. Peneliti membagikan angket pada masing-masing siswa diakhir pertemuan.

b. Peneliti mengarahkan siswa terlebih dahulu membaca angket sebelum menjawab.

c. Siswa memberi tanda centang $(\sqrt{ })$ pada kolom pilihan sesuai dengan pendapatnya sendiri disertai alasan terhadap pertanyaan yang diberikan pada tempat yang telah disediakan.

4. Data tentang keteraksanaan pembelajaran diperoleh dengan menggunakan lembar observasi keterlaksanaan pembelajaran. Adapun langkah-langkah pengumpulan datanya sebagai berikut:

a. Observer/pengamat mengambil tempat yang sekondusif mungkin sehingga peneliti teramati dengan baik.

b. Memberi tanda centang $(\sqrt{ })$ pada kolom terlaksana, menyangkut kemampuan guru dalam pengelolaan kegiatan belajar mengajar berdasarkan skala penilaian sebagai berikut: (1) kurang; (2) cukup; (3) baik; dan (4) sangat baik.

Dalam penelitian ini data yang dianalisis yaitu hasil belajar siswa, respon siswa, dan keaktifan siswa dengan Model ARIAS.

\section{HASIL DAN PEMBAHASAN}

\section{Hasil Belajar Siswa}

Hasil analisis statistik deskriptif yaitu hasil observasi keterlaksanaan pembelajaran, hasil tes kemampuan awal sebelum dan peningkatan hasil belajar sesudah diterapkannya pendekatan ARIAS pada pembelajaran matematika, hasil observasi aktivitas siswa, hasil angket 
respons siswa terhadap pembelajaran matematika melalui model ARIAS (Assurance, Relevance, Interest, Assessment, Satisfaction) pada siswa kelas VII SMPN 1 Tanete Riaja dengan VII.3 sebagai kelas eksperimen.

Pengamat melakukan penilaian terhadap kemampuan guru dalam mengelola pembelajaran dengan mengisi penilaian yang terdapat pada lembar observasi. penilaian tersebut terdiri dari 4 kategori yaitu (1) kurang, (2) cukup, (3) baik, (4) sangat baik.

Analisis aktivitas siswa dilakukan dengan maksud untuk mengetahui rata-rata keaktifan siswa kelas VII.3 SMPN 1 Tanete Riaja selama mengikuti proses pembelajaran dalam 4 kali pertemuan. Sesuia dengan indikator aktivitas siswa yaitu siswa dikatakan aktif jika rata-rata aktivitas siswa yang terlibat dalam pembelajaran berada pada kategori cukup. Dari hasil analisis data observasi dapat dilihat bahwa rata-rata aktivitas siswa kelas VII.3 SMPN 1 Tanete Riaja dalam pembelajaran matematika melalui Model ARIAS (Assurance, Relevance, Interest, Assessment, Satisfaction) adalah 79,56\% sehingga aktivitas siswa telah mencapai kriteria aktif.

Statistik skor hasil Pretest siswa kelas VII.3 SMPN 1 Tanete Riaja sebelum diterapkannya Model ARIAS (Assurance, Relevance, Interest, Assessment, Satisfaction) pada pokok bahasan bilangan bulat disajikan dalam Tabel 3 sebagai berikut.
Tabel 1

Deskripsi Skor Data Hasil Pretest dari 26 siswa

\begin{tabular}{ll}
\hline Statistik & $\begin{array}{l}\text { Nilai } \\
\text { Statistik }\end{array}$ \\
\hline Skor Tertinggi & 47,00 \\
\hline Skor Terendah & 3,00 \\
\hline Skor Ideal & 100,00 \\
\hline Rentang Skor & 44,00 \\
\hline Skor Rata-rata & 16,15 \\
\hline Variansi & 208,38 \\
\hline Standar Deviasi & 14,44 \\
\hline
\end{tabular}

Berdasarkan Tabel 1 dapat dilihat bahwa skor rata-rata nilai pretest siswa kelas VII.3 SMPN 1 Tanete Riaja pada pokok bahasan bilangan bulat adalah 16,15 dari skor ideal 100 dengan standar deviasi 14,44. Skor yang dicapai siswa tersebar dari skor terendah 3 sampai dengan skor tertinggi 47 dengan rentang 44 .

Jika skor hasil posttest dikelompokkan dalam lima kategori, maka diperoleh bahwa dari 26 siswa kelas VII.3 SMPN 1 Tanete Riaja, ada sekitar $100 \%$ atau 26 orang siswa yang skor hasil pretestnya berada pada kategori kurang, $0 \%$ atau tidak ada siswa yang skor hasil pretestnya berada pada kategori cukup, kategori baik dan kategori sangat baik.

Statistik skor hasil Posttest siswa kelas VII.3 SMPN 1 Tanete Riaja setelah diterapkannya Model ARIAS (Assurance, Relevance, Interest, Assessment, Satisfaction) pada pokok bahasan bilangan bulat disajikan dalam Tabel 2 sebagai berikut. 
Tabel 2

Deskripsi Skor Data Hasil Postest dari 26 siswa

\begin{tabular}{ll}
\hline Statistik & $\begin{array}{l}\text { Nilai } \\
\text { Statistik }\end{array}$ \\
\hline Skor Tertinggi & 82,00 \\
\hline Skor Terendah & 41,00 \\
\hline Skor Ideal & 100,00 \\
\hline Rentang Skor & 41,00 \\
\hline Skor Rata-rata & 71,19 \\
\hline Variansi & 112,56 \\
\hline Standar Deviasi & 10,61 \\
\hline
\end{tabular}

Berdasarkan Tabel 2 dapat dilihat bahwa skor rata-rata nilai posttest siswa kelas VII.3 SMPN 1 Tanete Riaja pada pokok bahasan bilangan bulat adalah 71,19 dari skor ideal 100 dengan standar deviasi 10,61. Skor yang dicapai siswa tersebar dari skor terendah 41 sampai dengan skor tertinggi 82 dengan rentang 41 .

Jika skor hasil posttest dikelompokkan dalam lima kategori, makamdapat diketahui bahwa dari 26 siswa kelas VII.3 SMPN 1 Tanete Riaja, ada sekitar $0 \%$ atau tidak ada siswa yang skor hasil posttestnya berada pada kategori sangat baik, $15,38 \%$ atau 4 orang siswa yang skor hasil posttestnya berada pada kategori baik, $61,54 \%$ atau 16 orang siswa yang skor hasil posttestnya berada pada kategori cukup, dan ada 23,08\% atau 6 orang siswa yang skor hasil posttestnya berada pada kategori kurang.

Ketuntasan hasil belajar matematika setelah diterapkannya Model ARIAS adalah sebagai berikut: terdapat 20 orang siswa atau $76,92 \%$ yang memenuhi kriteria ketuntasan individual dari 26 jumlah siswa. Sedangkan yang tidak memenuhi kriteria ketuntasan individual sebanyak 6 orang siswa atau 23,08\%. Jika dikaitkan dengan kriteria ketuntasan hasil belajar siswa, dapat disimpulkan bahwa hasil belajar siswa kelas VII.3 SMPN 1 Tanete Riaja setelah diterapkannya Model ARIAS (Assurance, Relevance, Interest, Assessment, Satisfaction) telah memenuhi kriteria ketuntasan hasil belajar secara klasikal yaitu $\geq$ $75 \%$.

\section{Aktivitas Siswa}

Hasil pengamatan aktivitas siswa dalam pembelajaran matematika melalui Model ARIAS (Assurance, Relevance, Interest, Assessment, Satisfaction) dengan pada siswa kelas VII.3 SMPN 1 Tanete Riaja menunjukkan bahwa siswa aktif saat pembelajaraan berlangsung. Dalam hasil pengamatan aktivitas siswa terlihat bahwa guru dan siswa aktif, di mana diperoleh bahwa rata-rata skor aktivitas siswa dari pertemuan pertama sampai pertemuan keempat telah memenuhi kriteria keefektifan aktivitas siswa yaitu $\geq 75$, yaitu 79,56. Hal ini menunjukkan bahwa secara umum dari pertemuan pertama sampai pertemuan keempat, siswa yang diobservasi telah melaksanakan aktivitas dalam Model ARIAS (Assurance, Relevance, Interest, Assessment, Satisfaction) sesuai yang diharapkan. 


\section{Respon Siswa}

Data tentang respons siswa terhadap pembelajaran matematika melalui Model ARIAS (Assurance, Relevance, Interest, Assessment, Satisfaction) diperoleh melalui pemberian angket respons siswa yang selanjutnya dikumpulkan dan dianalisis. Secara umum rata-rata siswa kelas VII.3 SMPN 1 Tanete Riaja memberi respons positif terhadap pelaksanaan pembelajaran melalui Model ARIAS (Assurance, Relevance, Interest, Assessment, Satisfaction), dengan rata-rata persentase respons siswa adalah 90,86\%. Dengan demikian respons siswa yang diajar dengan pendekatan ini dapat dikatakan efektif karena telah memenuhi kriteria respons siswa yakni $\geq 75 \%$ siswa memberikan respons positif.

Dari hasil analisis deskriptif yang diperoleh, ternyata cukup mendukung teori yang telah dikemukakan pada kajian teori. Dengan demikian dapat disimpulkan bahwa "Model ARIAS (Assurance, Relevance, Interest, Assessment, Satisfaction) efektif diterapkan dalam pembelajaran matematika pada siswa kelas VII SMPN 1 Tanete Riaja”.

\section{SIMPULAN DAN SARAN}

Berdasarkan hasil analisis data dan pembahasan yang telah dipaparkan sebelumnya, dapat ditarik simpulan bahwa:

1. Hasil belajar dengan
menggunakan Model ARIAS lebih dari 69,99 dengan memenuhi criteria ketuntasan $75 \%$ yaitu siswa yang tuntas sebanyak 20 orang dengan rata-rata $76,92 \%$.

2. Aktivitas siswa yang telah diamati selama empat kali pertemuan mencapai kriteria ketuntasan dengan skor rata-rata (\%) aktivitas siswa berada pada kategori cukup dengan skor nilai $79,56 \%$, dengan begitu aktivitas siswa mencapai kriteria aktif.

3. Respons berdasarkan seluruh aspek, rata-rata persentase respons siswa terhadap Model ARIAS (Assurance, Relevance, Interest, Assessment, Satisfaction) pada pembelajaran matematika mencapai $90,86 \%$. Hal ini berarti bahwa secara keseluruhan siswa menunjukkan respons yang positif sebagaimana kriteria yang telah ditetapkan sebelumnya yaitu $\geq$ $75 \%$.

Berdasarkan hasil penelitian yang telah diperoleh maka peneliti mengajukan beberapa saran sebagai berikut.

1. Kepada guru bidang studi matematika agar lebih banyak memberikan soal-soal latihan untuk dikerjakan oleh siswa selama di kelas maupun di rumah dengan tingkatan soal yang berbeda, mulai dari soal yang mudah sampai soal yang dirasa sulit. Ini dimaksudkan agar siswa lebih jika menghadapi soal serta percaya diri dengan kemampuannya dalam menyelesaikan soal-soal matematika.

2. Kepada para peneliti dalam bidang pendidikan matematika supaya dapat meneliiti lebih jauh tentang 
pendekatan, model maupun metode yang efektif dan efisien untuk dapat digunakan dalam mengatasi berbagai kesulitan yang dialami oleh siswa dalam belajar matematika.

\section{DAFTAR PUSTAKA}

Brandt, Jim, dkk. 2016. Mathematicians and Math Educators' Views on "Doing Mathematics". Journal PRIMUS > Problems, Resources, and Issues in Mathematics Undergraduate Studies. (Online) vol. 26, No. 8 ,

(https://www.tandfonline.com/d oi/full/10.1080/10511970.2016. 1166408 diakses pada $12 \mathrm{Mei}$ 2018).

Rahman, M dan Sofan, A. 2014. Model Pembelajaran ARIAS (Assurance, Relevance, Interest, Assessment, Satisfaction) Terintegratif. Jakarta: PT. Prestasi Pustaka.

Suprijono, Agus. 2015.Cooperative Learning: Teori dan Aplikasi PAIKEM. Yogyakarta: Pustaka Pelajar.

Tiro, M. Arif \& Ahmar, Ansari Saleh. 2014. Penelitian Eksperimen. Makassar: Andira Publisher. 